\title{
How Africans Shaped British Colonial Institutions: Evidence from Local Taxation
}

\author{
JutTa Bolt And Leigh Gardner
}

\begin{abstract}
The institutions that governed most of the rural population in British colonial Africa have been neglected in the literature on colonialism. We use new data on local governments, or "Native Authorities," to present the first quantitative comparison of African institutions under indirect rule in four colonies in 1948: Nigeria, the Gold Coast, Nyasaland, and Kenya. Tax data show that Native Authorities' capacity varied within and between colonies, due to both underlying economic inequalities and African elites' relations with the colonial government. Our findings suggest that Africans had a bigger hand in shaping British colonial institutions than often acknowledged.
\end{abstract}

\section{In 1980, historian and former colonial officer Anthony Kirk-Greene drew attention to the small number of European officers in British colo- nial governments in Africa. He called this the "thin white line" (Kirk- Greene 1980, pp. 38-41). Nevertheless, he did not consider the colonial administration in danger of collapse, since large numbers of Africans had roles in it, particularly in governing the rural interior.}

The Journal of Economic History, Vol. 80, No. 4 (December 2020). (C) The Economic History Association. doi: 10.1017/S0022050720000455. This is an Open Access article, distributed under the terms of the Creative Commons Attribution license (http://creativecommons.org/ licenses/by/4.0/), which permits unrestricted reuse, distribution, and reproduction in any medium, provided the original work is properly cited.

Jutta Bolt is Associate Professor, Department of Economic History, Lund University, Lund, Sweden, and Faculty of Economics and Business, Department of Econometrics and Finance, University of Groningen, Groningen, Netherlands. E-mail: j.bolt@rug.nl. Leigh Gardner is Associate Professor, London School of Economics, Department of Economic History, London, United Kingdom, and a Research Affiliate in the Department of Economics, Stellenbosch University, Stellenbosch, South Africa. E-mail: 1.a.gardner@1se.ac.uk.

This paper has benefitted from the contributions of a number of people, particularly Ralph Austen, Gareth Austin, Robert Bates, Bas van Bavel, Catherine Boone, Steve Broadberry, Denis Cogneau, Yannick Dupraz, Johan Fourie, Ewout Frankema, Elliott Green, Michiel de Haas, Linda Heywood, Di Kilpert, Andrew Linke, Oliver Morrissey, Derek Peterson, Sandra de Pleijt, Maarten Prak, Marcel Timmer, John Thornton, Marlous van Waijenburg, Richard Waller, and Jan Luiten van Zanden. It has also gained from seminar and conference audiences at Harvard University, the London School of Economics, Lund University, New York University Abu Dhabi, Stellenbosch University, University of Nottingham, University of Southern Denmark, and Utrecht University, as well as the annual meetings of the African Economic History Network, the African Studies Association, the African Studies Association UK, the Economic History Association, and the Economic History Society. Attendees at the World Economic History Congress and the capstone conference of the National History Center's conference on decolonization have also made valuable contributions. This research was supported by funding from the Knut and Alice Wallenberg Foundation (grant number KAW 2016.0184) and the ESRC as part of the Spatial Inequalities in African Political Economy project (ES/R005753). Any remaining errors are our own. 
His observation is a salutary caution to writers on colonial institutions in Africa. Too much of the recent work on the legacies of colonial rule has focused on what happened in colonial capitals rather than in rural areas, and on the nature of national rather than local institutions (Bertocchi and Canova 2002; Lange, Mahoney, and vom Hau 2006; La Porta, Lopezde-Silanes, and Shleifer 2008; Acemoglu and Robinson 2012; Easterly and Levine 2016). This work has been criticized for taking a Eurocentric approach to understanding colonial institutions, treating colonies as an institutional "blank slate," which European colonizers could govern without reference to indigenous institutions (Bayly 2008).

Others, however, have argued that indigenous and precolonial institutions continued to be more important than national institutions in shaping African development through the colonial period and beyond (Gennaioli and Rainer 2007; Michalopoulos and Papaioannou 2013, 2014; Bandyopadhyay and Green 2016). To support this argument, these papers correlate anthropological measures of African state centralization from the Murdock Atlas (Murdock 1967), interpreted as a measure of "pre-colonial" state capacity, with later economic and political outcomes. However, such correlations say little about how interactions with colonial governments may have influenced African institutions during the colonial period. Archibong $(2018,2019)$ is an exception, paying welcome attention to the relationship between African institutions and the colonial state in Nigeria.

There is a rich qualitative literature on the ways in which Africans and African institutions responded to the evolving incentives of the colonial period (e.g. Mamdani 1996; Spear 2003). This work shows that African local governments, known at the time as "Native Authorities," did not just preserve past institutions. Rather, the integration of African rulers into colonial administrations altered their sources of legitimacy and accountability, and both Africans and Europeans reinterpreted indigenous political traditions to suit changing circumstances. To date, however, the evidence used in these discussions has been largely anecdotal.

This paper presents new data on the structure and capacity of Native Authorities for four British colonies, Nigeria, the Gold Coast (now Ghana), Nyasaland (now Malawi), and Kenya, and uses these data to argue that the interaction of colonial officials and African elites during the colonial period created substantial variation in colonial institutions both within and between colonies. The data are based on a set of districtlevel surveys commissioned in 1948 for Lord Hailey's five-volume report entitled Native Administration in the British African Territories (Hailey 1951). The surveys were completed by district officers and are now held 
by the British National Archives. ${ }^{1}$ They asked a standard set of questions about the physical, economic, and demographic characteristics of each Native Authority area (of which there were often several in a district) and about the structure of the Native Authority, its finances, and its activities. They provide a rare quantitative and comparative account of these institutions both within and between British colonies in Africa.

These four colonies had a range of different types of colonial economies and political structures. In 1950, Britain had 15 colonies in Africa, including some of the smallest in the region and some of the largest (see Figure 1). Their wide range of colonial histories makes it difficult to identify representative cases. One reason for choosing these four is that they contained just over half of the African population under British rule in 1950 (52.7 percent, using population estimates from Frankema and Jerven (2014)). Using the widely cited typology developed by Samir Amin (1973), our selection includes colonies dominated by peasant production (Nigeria and the Gold Coast) and colonies with European settlers and large-scale expatriate production (Kenya and Nyasaland). The Gold Coast was one of British Africa's export success stories, while Nyasaland was one of Britain's poorest colonies. All four incorporated different types of indigenous institutions, from hierarchical states to decentralized villagebased societies. Due to these differences, they provide good empirical evidence to support our argument that interactions between Africans and Europeans created a landscape of colonial institutions that varied enormously both within and between different colonies.

We use tax revenue from c. 1948 as a measure of the capacity of Native Authorities. ${ }^{2}$ The structure of tax systems and the amount of revenue they produce have become important for comparing and measuring state capacity in different historical periods and contexts (Dincecco 2011; Karaman and Pamuk 2013). This approach has been used in comparative studies of colonial states in Africa to examine the capacity of central governments (e.g., Mkandawire 2010; Frankema and van Waijenburg 2014). But this work has largely ignored local governments, thus neglecting a significant component of colonial fiscal systems. ${ }^{3}$ By the end of the colonial period, local government spending as a share of total government spending was over 20 percent in highly decentralized

\footnotetext{
${ }^{1}$ U.K. National Archives CO 1018, various files. The specific files used here are as follows: Gold Coast, CO 1018/10, CO 1018/11, CO 1018/15; Kenya, CO 1018/22, CO 1018/23, CO $1018 / 24$, CO 1018/25, CO 1018/25, CO 1018/27; Nyasaland, CO 1018/58, CO 1018/59, CO 1018/60; Nigeria, CO 1018/36, CO 1018/38, CO 1018/39, CO 1018/40.

${ }^{2}$ Dates may vary by a year or two depending on data availability. See Online Appendix 1 for detailed definitions of variables and country-specific lists of sources.

${ }^{3}$ Hoffman (2015, p. 308). For a partial exception, see Gardner (2012).
} 


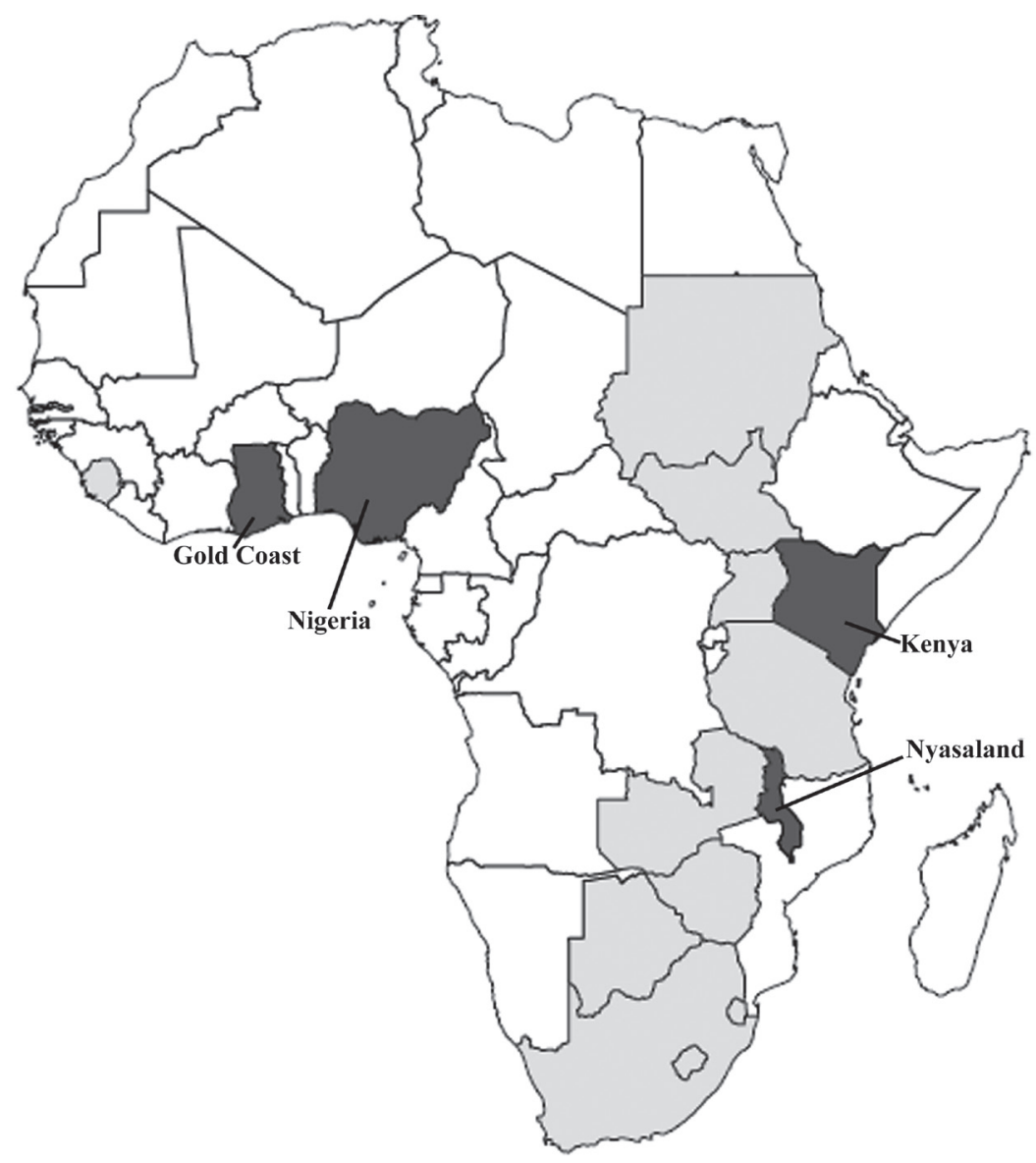

FIGURE 1

BRITISH COLONIAL AFRICA WITH SELECTED CASES

Source: Based on Reid (2009, p. 201). The map does not include divided territories such as Somaliland, Togo, or the Cameroons.

colonies, such as Nigeria and Uganda, and between 5 and 10 percent in most others. ${ }^{4}$ Even where the overall share was small, this local spending was nevertheless important from the perspective of the African population. The biggest items in national colonial governments' budgets tended to be salaries for urban European officials or funds for building railways (Frankema 2011). However, most of the population was rural-in the four colonies studied here, between 60 and 85 percent of the labor force was employed in agriculture in the 1960s (Broadberry and Gardner 2016,

\footnotetext{
${ }^{4}$ To put this in today's context, a 2008 study of decentralization levels in 20 Sub-Saharan Africa countries found that an average of 14 percent of total government expenditure was incurred by subnational units (Dziobek et al. 2011, p. 23).
} 
p. 26). For this part of the population, it was the Native Authorities who provided many government services, including a system of courts, local regulation of land and markets, and some local education and health care. The scale and quality of these services depended on how much revenue Native Authorities could collect.

We show that the substantial variation in tax revenue collected by Native Authorities reflects not only regional economic inequalities but also differences in the institutions that developed during the colonial period as a result of the different ways in which African institutions were integrated into the machinery of British colonial rule. This suggests that we need a new approach to the study of British colonial institutions in Africa, one that treats them neither as purely European inventions nor as simply the continuation of pre-colonial systems, but rather, as we argue here, as the outcome of interactions between Africans and Europeans. In this paper, we take a first step toward quantifying the structure and capacity of local institutions created through these interactions.

\section{A SHORT HISTORY OF INDIRECT RULE IN BRITISH AFRICA}

Sub-Saharan Africa was one of the last regions to be colonized by European powers. By that stage, they were not prepared to invest large sums in establishing an administrative apparatus in the colonies, which meant that colonial governments had to support recurrent expenditure with limited local revenue collections (Gardner 2012) and, thus, had to leave many of the main tasks of governing in the hands of Africans (Iliffe 2007, p. 193). The African local governments or "Native Authorities" established in the decades before 1914 were, thus, the vital link between the majority of the African population and the skeletal European administrations. One report from Nyasaland (1937, Appendix 1) described the Native Authority as "the executive government in all matters pertaining to natives."

However, the process by which Native Authorities were established, and the degree of power that colonial governments delegated to them, differed both within and between colonies. While it is common for "indirect rule" to be contrasted with "direct rule," these were not distinct types. Relationships between indigenous institutions and colonial administrations varied, resulting in different degrees of shared authority (Gerring et al. 2011, pp. 382-83; Naseemullah and Staniland 2016, p. 13). Lord Hailey (1942, p. 13) deliberately avoided using the phrase indirect rule, saying it had "no claim to precision." As a system of governance, indirect rule was only vaguely defined and implemented differently across 
colonial Africa (Dudley 1968, pp. 13-14). In his study of southeastern Nigeria, for example, Afigbo (1972, p. 3) argues that excessive emphasis on the system developed in northern Nigeria, "described erroneously as the classical pattern," has distorted our understanding of the variety of practices found across British Africa.

European colonizers encountered a wide range of indigenous institutions in Africa (Osadolor and Otoide 2005, p. 159; Osafo-Kwaako and Robinson 2013). They could be complex, hierarchical, and highly centralized, as in kingdoms such as Asante, Buganda, and the emirates of northern Nigeria, or horizontally oriented based on villages or clans in which decisions were made collectively by representatives of lineages or age sets. The latter included the Igbo in Nigeria or the Maasai and Luo in Kenya (Hawthorne 2013, pp. 78-79). In their classic work on African political systems, anthropologists Meyer Fortes and Edward EvansPritchard (1966, p. 5) divide them into Group A, "societies which have centralized authority, administrative machinery and judicial institutions," and Group B, segmentary societies, which lack those features and "in which there are no sharp divisions of rank, status or wealth."

African institutions experienced considerable upheaval throughout the nineteenth century, linked to both external and internal shifts (Boahen 1989; Ogbomo 2005; Iliffe 2007, pp. 164-92). The peak of the Atlantic slave trade in the eighteenth century, followed by its end in the nineteenth, the Fulani jihads, and the Zulu Mfecane all caused disruptions of various types across wide swathes of the region. During this period, some older states, such as the Oyo Empire in what became Nigeria, declined, while others, such as Ibadan in Nigeria or Asante in what became the Gold Coast, expanded their power at the expense of those that had begun to fade.

Colonial conquest brought its own disruptions above and beyond the considerable violence of colonial wars (Falola 2009; Huillery 2011). Colonial governments hoped that they could minimize disruption by incorporating existing institutions into the colonial administration (Berry 1992, p. 329). The way they did this in each colony depended on how they perceived African institutions and how Africans responded to their interventions. In northern Nigeria, where states were already highly centralized and most of the Fulani aristocracy were willing to cooperate with the British in exchange for political support, Lord Lugard merely placed the British colonial government at the top of an existing hierarchical system. In such cases, the emirs often enjoyed increased internal authority even while ceding external power (Paden 1970, p. 163). However, where states resisted British rule, as in the case of Asante, the British government 
often took steps to strengthen rivals by allocating territorial and political authority (Berry 1992, p. 332). In Nigeria, when Ibadan proved less than cooperative, British officials attempted to revive the old supremacy of Oyo (Atanda 1970, pp. 215-16).

In regions with less identifiably centralized institutions, the creation of Native Authorities was more likely to involve the appointment of chiefs by European district officers than the identification of those with existing legitimacy. In the northern Gold Coast, for example, those chiefs who "appeared to have the necessary authority ... were recognized as agencies" for the maintenance of law and order, but "in other cases chiefdoms were created by the appointment of persons who seemed to possess local prestige or authority" (Hailey 1951, p. 262). Kenya's 1902 Village Headmen Ordinance, which made village headmen responsible for law and order in their villages, called for the appointment of said headmen by European officials and gave them little power (Hailey 1951, p. 92). Similarly, in Nyasaland, the 1912 District Administration (Native) Ordinance mandated the appointment of village headmen and principal headmen. It did not exclude "the use of traditional Native Authorities as agencies of local rule" but intended the headmen to act "mainly as executive agents of the Administration" (Hailey 1951, pp. 25-26). In southeastern Nigeria, such appointees were described derisively as "warrant chiefs," whose only authority came from their link to the British colonial administration (Afigbo 1972).

By 1914, when the initial construction of colonial administrations in Africa was largely complete, Native Authorities included everything from appointed village heads to powerful emirs who had signed treaties with the British government. Colonial authorities referred to all of these figures as "chiefs" and, at this point, chiefs alone constituted Native Authorities, which formed the "executive government" by which British colonial administrations governed the vast majority of their African territory.

During the interwar period, colonial governments across British Africa attempted to reform and expand this system, granting to Native Authorities new powers of taxation and new responsibilities for the provision of government services. In some Native Authorities, councils were established to expand political access to groups outside traditional hierarchies, including migrants and those educated in mission schools. In these, the Native Authority was no longer just the chief but rather the chief in council. Many histories of colonial governance in British Africa explain this as an effort to channel the growing political activism of Africans toward local rather than national governance (see, e.g., Lonsdale 1968). 


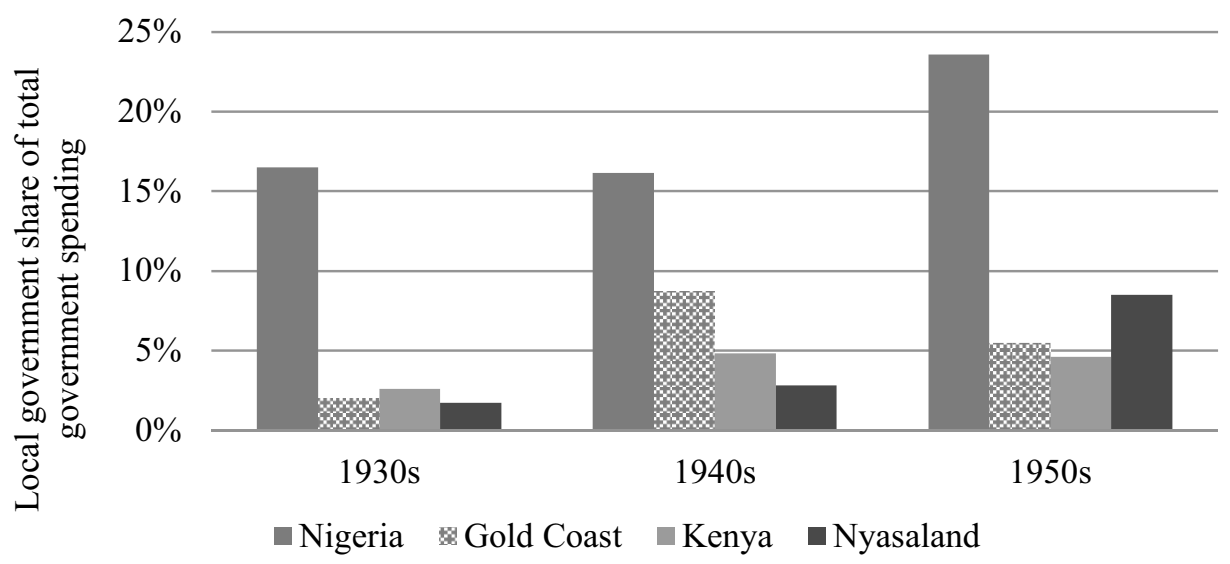

FIGURE 2

FISCAL DECENTRALIZATION

Sources: National expenditure figures from Blue Books before 1945 and Financial Reports thereafter. Data on local government finances from Gold Coast (1952); Kenya (1948, 1949); Nigeria, Native Treasury Estimates 1947-9, in U.K. National Archives CO 1019/41; Nyasaland, "Economic Statistics," in U.K. National Archives CO 1015/422; and Nyasaland (various, 1937).

Decentralization also gave colonial governments a means of responding to demand for increased provision of education and other services without overburdening central government budgets (Gardner 2012, pp. 161-91).

Contemporaries described reforms to the Native Authority system as an effort to transform African institutions into a more bureaucratic system of local government (Hicks 1961, p. 8). Perhaps the most important of these changes was the establishment of Native Treasuries and the granting of powers to levy taxes (known as local rates). In Nigeria, Native Treasuries were established in 1917 with the passing of the Native Revenue Ordinance. In the other three colonies in our sample, treasuries were not introduced until the 1930s. ${ }^{5}$ The establishment of Native Treasuries and increase in Native Authority revenue led to an increase in fiscal decentralization in British Africa, even in colonies that had been highly centralized in previous decades. This is shown in Figure 2, with decentralization measured as local government's share of total government spending.

Along with powers to tax came new powers and responsibilities for service provision. In Kenya, for example, the 1937 Native Authority Ordinance gave Local Native Councils control over a range of local

\footnotetext{
${ }^{5}$ The relevant laws were as follows: 1933 Native Authority Ordinance (Nyasaland), 1937 Native Authority Ordinance (Kenya), and Ordinance No. 25 of 1936 and the 1939 Native Administration Treasuries Ordinance (Gold Coast).
} 
government policies, from the control of water supplies to the regulation of grazing and the cutting of timber (Hailey 1951, p. 93). Service provision included the operation of schools and clinics. The extent of these services depended on the Native Authorities' budgets. For example, the budget of the North Kavirondo Local Native Council in Kenya, as submitted to Lord Hailey, shows that in 1947 the LNC spent approximately 30 percent of its budget on education, 29 percent on agricultural services, and 9 percent on public health and social welfare. Just 9 percent was spent on administration - principally the salaries of chiefs and their councilors. By contrast, the Mlange Native Authority in Nyasaland spent 47 percent of its budget on administration, and the District Commissioner wrote in his survey response that this did not "leave much" for other priorities.

The availability of resources was directly related to the decentralization of service responsibilities to Native Authorities. The 1937 Nyasaland memorandum cited earlier stated that responsibilities for the extension of services by Native Authorities would not be approved until the budget contained "full provision for the transferred or extended service" and the Native Authority could support both capital expenditure and recurrent expenditure. This had political as well as financial motives. "Unless the Native Authority actually pays," the memorandum argued, "it will be difficult to make the Native Authority and people believe that the transferred service is actually transferred." In other words, the ability of the Native Authority to act without interference from the colonial government depended on the amount of revenue it could raise.

The Native Authorities varied widely in their ability to cope with these new responsibilities (Hinden 1950, p. 32). A 1948 report by the colonial administration of Kenya observed that "a distressing feature, accentuated during the war, is the lack of uniformity in the rate of progress between the semi-sophisticated and the backward tribes in the colony. The inhabitants of Nyanza and Kikuyu areas of Central Province might be living in a different world from the Masai and Elgeyo, for example" (Kenya 1948).

\section{NATIVE AUTHORITIES}

Before the 1940s, information on Native Authority administrations and their finances is fragmentary, often presented only in aggregate form at the district or provincial level and recorded only in internal administrative reports and not in annual reports of statistics sent to the metropolitan government in London. Inadequate data may be one reason why local 
governments have been neglected in studies of colonial taxation, which rely heavily on these reports. However, policies of decentralization from the 1930s drew the imperial government's attention to the diversity of institutions and practices, prompting a demand for more systematic comparisons of Native Authorities. The eventual response to this demand provided the data that have enabled us to produce the first quantitative account of Native Authority institutions, making it possible to compare them within and between colonies.

A central figure in the British government's efforts to bring clarity to this subject was Lord Hailey, a retired Indian civil service officer who wrote a number of reports on colonial administration in Africa, beginning with his mammoth African Survey, published in 1938 (Hailey 1938; Cell 1989). The Survey has a chapter on Native Administration, which Hailey extended in 1942 with a brief study that was available at first only to government officials and a few selected scholars. In 1947, the Colonial Office asked him to bring this work up to date and the result was the report published in five volumes from 1951. To compile the report, Hailey sent questionnaires to district officers in ten British colonies in Africa (the Gambia, the Gold Coast, Kenya, Nigeria, Northern Rhodesia, Nyasaland, Sierra Leone, Tanganyika, Uganda, and Zanzibar), asking about the physical, economic, demographic, and institutional characteristics of each Native Authority area. ${ }^{6}$ The responses varied in their level of detail, with some providing long narrative accounts of the operations of local institutions and others restricting themselves to very short answers. Where necessary, we supplemented these data with data from other government reports from our four colonies.

Table 1 shows the area and populations of Native Treasury areas in the four colonies. Immediately noticeable is the wide variation in physical size and population. In Nigeria, for example, the smallest Native Treasury had just over 3,000 people while the largest had close to three million. The variation was less extreme in the other three colonies, but still substantial.

Michael Crowder and Obaro Ikime (1970, p. xiii) noted in their study of chiefs in West Africa that British preoccupations with the pre-colonial "legitimacy" of Native Authorities resulted in Native Authorities of many shapes and sizes. Attempts to combine them for administrative convenience often met with African opposition. In the Gold Coast, for example, the Kassena, Nankanni, and Builsa resisted colonial efforts to unite them under one Native Authority (Ladouceur 1979, p. 55).

\footnotetext{
${ }^{6}$ The questionnaire was the same for all colonies, apart from a few differences reflecting local conditions. For example, the questionnaires for Kenya and Nyasaland asked about the presence of European settlement and alienated land, which was unnecessary in the West African colonies.
} 
TABLE 1

AREA AND POPULATIONS OF NATIVE TREASURY AREAS C. 1948

\begin{tabular}{lccrrr}
\hline \hline & \multicolumn{5}{c}{ Population } \\
\cline { 2 - 6 } & $\begin{array}{c}\text { Number of Native } \\
\text { Authorities }\end{array}$ & \multicolumn{1}{c}{ Mean } & Std. Dev. & \multicolumn{1}{c}{ Min } & \multicolumn{1}{c}{ Max } \\
\hline Gold Coast & 91 & 37,685 & 56,920 & 1,587 & 378,586 \\
Nyasaland & 17 & 140,708 & 82,828 & 15,593 & 323,923 \\
Kenya & 27 & 168,470 & 170,876 & 15,341 & 633,568 \\
Nigeria & 226 & 153,796 & 312,249 & 3,273 & $2,882,414$ \\
\hline \multicolumn{7}{c}{} & Area $\left(\mathrm{km}^{2}\right)$ & & \\
\cline { 2 - 6 } & Number of Native & & & Min & Max \\
\hline Gold Coast & Authorities & Mean & Std. Dev. & 11 & 36,307 \\
Nyasaland & 91 & 2,639 & 5,020 & 310 & 14,681 \\
Kenya & 17 & 5,663 & 3,292 & 279 & 78,770 \\
Nigeria & 27 & 15,523 & 18,556 & 68 & 84,826 \\
\hline
\end{tabular}

Sources: Gold Coast (1948), Kenya (1949), Nigeria (1955), and Nyasaland economic statistics in U.K. National Archives CO 1015/522.

The political structures governing the colonial populations were far from uniform. For a start, chiefs could be chosen by "traditional selection" (hereditary, or from a small number of "chiefly" families, along patrilineal or matrilineal lines), elected by the local population, or appointed by the district officer. Traditional selection did not always mean that succession practices had been inherited from the pre-colonial period; in parts of Nyasaland, for example, chieftaincies initially occupied by government appointees became hereditary over time. Hailey's surveys asked whether chiefs could be removed, either by their constituents or the district officer. In some regions, removal of a chief by the people, known as "de-stooling," was common: in the Gold Coast, two thirds of the Native Authorities had experienced it. In other regions, chiefs effectively held the post for life: in Kenya, none of the surveys recorded the removal of Native Authorities.

The other two ingredients of the "mature" Native Authority system, as identified by Hicks (1961), were treasuries and courts. A Native Authority could have its own treasury, but often many smaller Native Authorities federated for financial purposes. In Nigeria, about half of the Native Authorities had done this, and in the Gold Coast, 10 of the 126. In Kenya, in contrast, all the Native Authorities had federated, and in Nyasaland, all but one.

Native Authorities had varying degrees of responsibility for managing their own assets. Those with literate members and some degree of fiscal knowledge set their own estimates; those without depended on the 
TABLE 2

SUMMARY STATISTICS OF INSTITUTIONAL STRUCTURES

OF NATIVE AUTHORITIES, C. 1948

\begin{tabular}{llcc}
\hline \hline \multicolumn{1}{c}{ Variable } & $\begin{array}{c}\text { Full } \\
\text { Sample }^{\mathrm{a}}\end{array}$ & $\begin{array}{c}\text { Regression } \\
\text { Sample }^{\mathrm{a}}\end{array}$ \\
\hline Autonomy & Traditional selection & $69 \%$ & $72 \%$ \\
& NA sets own estimates & $19 \%$ & $18 \%$ \\
& Presence of appeal court & $56 \%$ & $62 \%$ \\
\hline Voice and & Average no. of NAs per Treasury & 6 & 5 \\
accountability & NA can be removed by people & $28 \%$ & $31 \%$ \\
& NA elected by people & $24 \%$ & $20 \%$ \\
& Chief in council & $54 \%$ & $52 \%$ \\
& Solo chief & $21 \%$ & $26 \%$ \\
Observations & & $279-294^{\mathrm{b}}$ & 189 \\
\hline
\end{tabular}

Notes: ${ }^{\text {a Share of Native Authorities in the sample where the variable is present. }{ }^{b} \text { Number of }}$ observations differs per variable. The summary statistics for individual countries are presented in Online Appendix 2. A $t$-test shows that the two samples do not differ significantly.

Sources: Hailey surveys, U.K. National Archives CO 1018.

district officer to set them. Native Courts were responsible for hearing local cases, both civil and criminal, but their power to hear appeals or impose particular types of punishment varied. Table 2 summarizes measures of institutional differences for our four colonies, coded from the Hailey surveys. As mentioned above, the comprehensiveness of the survey responses varied. The table shows the full sample of observations and a subsample, which we use in the regression analysis below to make it easier to interpret changes in coefficient estimates.

The full sample consists of 361 Native Treasury areas in our four colonies. The total number of observations for each institutional indicator varies between 279 and 294. The regression sample, for which we have information for all variables, has 189 observations (Bolt and Gardner 2020). As Table 2 shows, the regression sample is very similar to the full sample in terms of the institutional characteristics of the Native Authorities.

The main measure of Native Authority capacity used in this paper is the per capita tax revenue collected by Native Authorities. Data on revenue per capita were available for 328 of the total 361 Native Treasury areas. As the fiscal data reported in the Hailey surveys vary in their level of detail, we supplemented them with data from other government reports. Table 3 presents the summary statistics of these data, for the full sample and the regression sample. The mean is the same in the two 
TABLE 3

SUMMARY STATISTICS OF REVENUE PER CAPITA, C. 1948

\begin{tabular}{lcccccc}
\hline \hline & $\begin{array}{c}\text { Number } \\
\text { of Native } \\
\text { Authorities }\end{array}$ & Mean & $\begin{array}{c}\text { Std. } \\
\text { Dev. }\end{array}$ & Min. & Max. \\
\hline Revenue per capita, pence (full sample) & 328 & 39 & 33 & 0.21 & 272 \\
Revenue per capita, pence (reg. sample) & 189 & 39 & 28 & 3 & 138 \\
\hline
\end{tabular}

Sources: Gold Coast (1952); Kenya (1949); Nigeria, Native Treasury Estimates 1947-9, in UK National Archives CO 1019/41; Nyasaland, "Economic Statistics," in U.K. National Archives CO 1015/422; and Nyasaland (various).

samples, but the variation in the full sample is unsurprisingly larger as the maximum amount of revenue collected is much higher. However, the 272 pence per capita collected in Effiduasi Sub-Division in the Gold Coast is an outlier and is not included in the regression sample due to missing observations for variables other than revenue per capita. Removing it lowers the maximum amount of revenue collected in the full sample to 187 pence per capita, which reduces the standard deviation to 30.5 , much closer to the corresponding figure for the regression sample.

Figure 3 maps these statistics onto the boundaries of the Native Treasury areas, digitized from archival maps. ${ }^{7}$ Our paper is the first to digitize these boundaries, allowing for spatial analysis of the nature and capacity of African institutions. Revenue per capita in all four maps is shown on the same scale, illustrating its considerable variation within and between colonies. In all four maps, white indicates "no data." These were areas where we could not match the names on colonial maps to fiscal data or, in the case of Kenya in particular, to areas of European settlement where local governments were led by Europeans.

Johnson and Koyama $(2017$, p. 2) define state capacity as the "ability of a state to collect taxes, enforce law and order, and provide public goods." Tax data have long been an important source of information in work on institutions and state building, both historically and today. There are two reasons for this. One is that taxation is linked to broader issues of state capacity, governments' relationship to taxpayers, changing

\footnotetext{
${ }^{7}$ Maps were sourced from several archives: Gold Coast, "Native States," 1946, British Library 65356 (19); Kenya, Map of the Colony and Protectorate of Kenya Showing District Boundaries and Provinces (1936), U.K. National Archives CO 533/470/1; Nyasaland, "British Central Africa 1906," Royal Geographical Society mr Malawi G.11. The Nigeria map was compiled from regional and provincial maps: Eastern, Local Government, Royal Geographic Society mr Nigeria Div. 34; Western, Provincial Maps, Bodleian Library (Abeokuta E39:10(1), Benin E39:13(2), Ijebu E39:19(1), Ondo E39:26(1), Oyo E39:29(2), Warri E39.34(1)); Northern, Native Authority Areas, Bodleian Library E39:1(22).
} 
A. Gold Coast

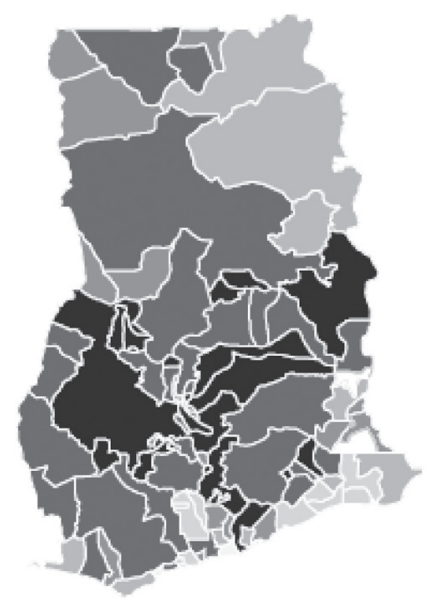

Revenue pc

\begin{tabular}{|l|l|}
\hline & no data \\
$0-10$ \\
$10-20$ \\
$20-35$ \\
$35-50$ \\
$50-100$ \\
$>100$ \\
\hline
\end{tabular}

C. Kenya

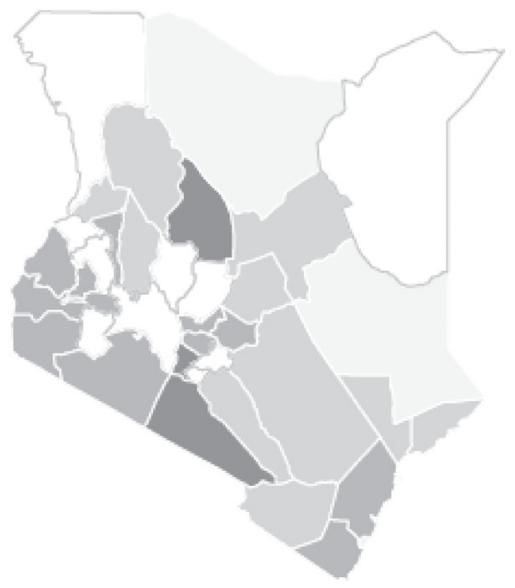

B. Nigeria

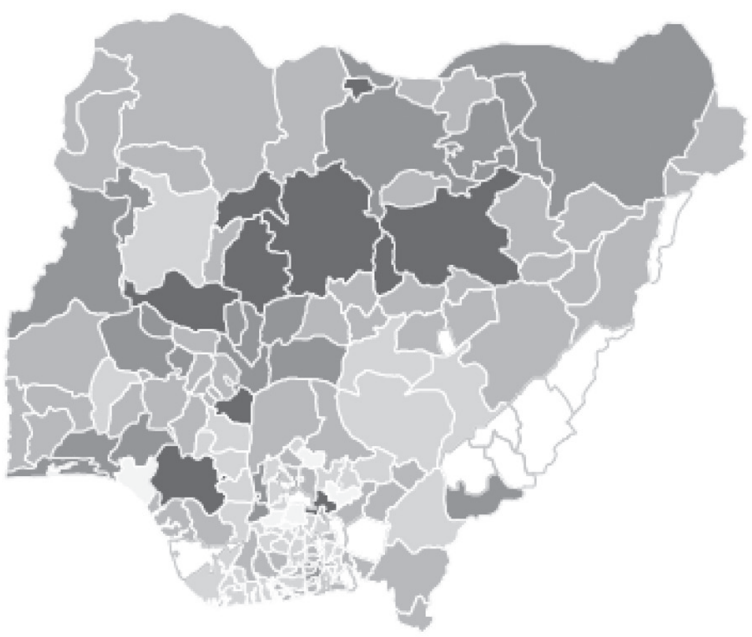

Revenue pc

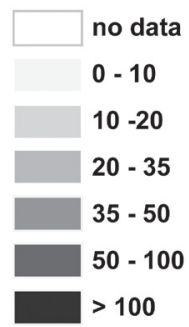

Revenue pc

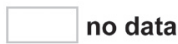

$0-10$

$10-20$

20 - 35

$35-50$

$50-100$

$>100$
D. Nyasaland

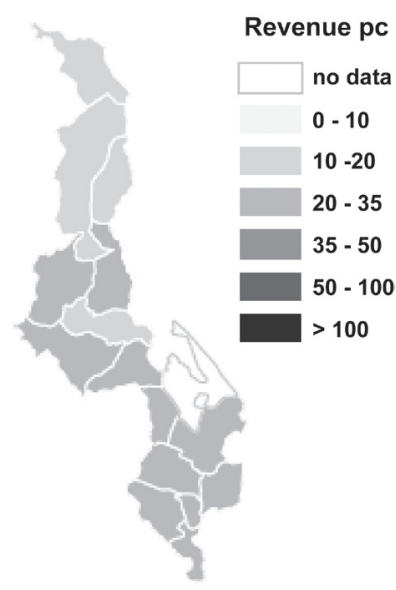

FIGURE 3

NATIVE AUTHORITY REVENUE PER CAPITA (CURRENT PENCE)

Sources: Table 3. Sources of maps in footnote 7. 
institutional structures, and economic development (Schumpeter 1954; Levi 1988; Tilly 1990). Today, there is a strong correlation between tax revenues and per capita income, though the direction of the relationship is not always clear (Dincecco 2011, pp. 2-3). The second reason is that tax data are both widely available and easily comparable (Lieberman 2002, pp. 89-90). In this literature, different types of tax revenue are often interpreted as measuring different things. Some types of revenue, such as that from income or other direct taxes, may be a better indicator of state capacity than others, such as that from trade or resource taxes. The relative shares of direct and indirect tax revenue are often used as an indicator of state capacity (Mkandawire 2010; Frankema and van Waijenburg 2014). ${ }^{8}$

Unlike central colonial governments, Native Authorities did not collect trade taxes. Their revenue sources can be broken down into three categories: direct taxes imposed by the Native Authorities themselves, referred to as "local rates"; rebates on direct taxes imposed by the colonial government; and fines or license fees of various kinds. The third category includes fees paid for market licenses, court fines, and sometimes royalties for natural resources. These tended to be a relatively small share of total revenue, meaning the biggest source was direct taxes. In Nigeria and Nyasaland, Native Authorities were responsible for collecting tax revenue for the central government and received a share of that revenue, which varied over time and, sometimes, between Native Authorities. There was no revenue sharing between the central government and Native Authorities in Kenya and the Gold Coast.

Some examples will make the picture clear. Gonja in the northern Gold Coast received approximately $£ 5,400$ from local rates, $£ 400$ from cattle tax, $£ 400$ from market fees, $£ 400$ from fishing licenses, $£ 600$ from the rental of kraals, and $£ 210$ from Native Authority ferries. Zaria in northern Nigeria collected $£ 74,000$ in general tax (exclusive of payments to the central government), $£ 10,000$ in jangali or cattle tax, $£ 5,000$ in fees from Native Courts, and $£ 1,000$ from interest on investments. In much of northern Nigeria, the taxes collected by Native Administrations built on elaborate systems of pre-colonial taxation, which included zakat, a Muslim charitable tax, as well as jangali and other agricultural taxes (Okauru 2012, pp. 69-71).

One source of revenue that cannot be documented in any systematic way was forced labor. As Marlous van Waijenburg (2018) has shown,

\footnotetext{
${ }^{8}$ De Roo (2017) argues that the need to establish control over trade routes to collect customs tariffs means revenue from this source can also act as an indicator of state capacity.
} 
tax payments in the form of labor could represent an important source of implicit revenue for colonial states in French Africa, adding as much as 100 percent to total revenue in some cases. In British Africa, Native Authorities used forced labor to construct and maintain roads and other infrastructure (Roberts 2017). However, we have no data on the extent of this practice or its geographical variation. The absence of the necessary records reflects British government obfuscation of this matter at the time, in an attempt to claim formal compliance with international agreements, such as the 1926 Convention on Slavery, without disrupting existing practices (Miers 1998).

The incorporation of revenue from forced labor into the quantitative study of African fiscal systems is relatively new, and the relationship between revenue from forced labor and state capacity remains less clear than for cash revenue. On the one hand, van Waijenburg's data show that labor taxes represented a larger share of total revenue during the early colonial period, when the capacity of colonial states was low. On the other, the mobilization of forced labor requires coercive capacity, and according to her data, the total amount of forced labor used in French Africa went up as state capacity in French colonies increased, even as cash revenue went up at a faster rate. It seems reasonable to speculate that if data were available on forced labor mobilized by Native Authorities, this would increase the variation in our sample rather than decrease it.

In the following three sections, using data from the Hailey surveys and other sources, and drawing on theories about taxation and state capacity in Africa and elsewhere, we look at the relationship between Native Authority revenue and regional economic inequalities, intergovernmental relations, and the structure of the Native Authorities. The first section looks at market access and other proxies for higher agricultural incomes; the second at differences in Native Authority autonomy, drawing on local government finance literature that suggests a relationship between power sharing and local taxation; and the third at how the per capita revenue varied with the institutional structure of the Native Authorities in 1948. In all three sections, our analysis is descriptive and does not claim to establish the direction of causation in any of the relationships shown. However, taken together, the three sections show that variations within and between colonies in the per capita revenue of Native Authorities did not merely reflect differences in market access or the traditional structure of African institutions; they also reflected differences in the institutions' structure that grew out of differences in the way indirect rule was implemented across British colonial Africa. 


\section{REGIONAL ECONOMIC INEQUALITIES AND NATIVE AUTHORITY REVENUE}

One difficulty in using tax revenue as an indicator of state capacity is that factors other than state capacity can influence levels of tax revenue, in particular overall income levels and the structure of the economy (Teera and Hudson 2004, p. 786; Karaman and Pamuk 2013, p. 607). This section investigates the relationship of Native Authority tax revenue to underlying socioeconomic conditions. In their study of Uganda, Bandyopadhyay and Green (2016, p. 499) argue that the relationship they find between pre-colonial state centralization and contemporary development outcomes was the result of local economic inequalities that have persisted since the pre-colonial period. Therefore, it may be that the variations in tax revenue described in the previous section merely reflect similar underlying inequality. In many African countries today, spatial inequality remains comparatively high and explains a substantial share of overall inequality levels (Mveyange 2015; Lessmann and Seidel 2017).

In this analysis, our dependent variable is revenue per capita. Adjusting the revenue data for population takes into account the variation in the sizes of Native Authority jurisdictions. Unfortunately, no direct measures of per capita income are available for this period at this level of spatial disaggregation. ${ }^{9}$ Wages and prices for Anglophone Africa during the colonial period are presented as national averages and most likely reflect the situation in and around colonial capitals (Frankema and van Waijenburg 2012).$^{10}$ However, data are available on various proxies for the level of taxable surplus and the availability of "tax handles," or structural features of economies that facilitate taxation (Musgrave 1969; Chelliah 1971; Mkandawire 2010).

Agricultural production that is only used for subsistence is difficult to measure and tax, as governments are seldom willing to tax their constituents' staple foods (Teera and Hudson 2004, p. 789). Crops produced for the market provide easier opportunities for the collection of tax revenue, and our analysis includes a dummy variable for whether cash crops, such as cocoa or cotton, were produced in each Native Authority area. During the late nineteenth and early twentieth centuries, African exports of such crops expanded dramatically (Frankema, Williamson, and Woltjer 2018),

\footnotetext{
${ }^{9}$ The scarcity of subnational (local) data remains a major hurdle in Africa even today. See African Development Bank (2015).

${ }^{10}$ Deflating revenue per capita by these wages does not eliminate the variation in revenue per capita. However, since the wage data do not reflect local price levels, revenue per capita is presented here in nominal terms.
} 
raising the incomes of farmers both directly and indirectly. In Uganda, for example, peasant farmers produced modest amounts of cotton to supplement subsistence production, raising their incomes above unskilled market wages (de Haas 2017). In the Gold Coast, cocoa increased the incomes of those farmers who adopted it and also provided a larger domestic market for food producers through specialization in agricultural labor (Aboagye and Bolt 2018). The expansion in the demand for food crops meant African farmers could now market their goods even in colonies where export crops were primarily produced by foreign-owned plantations or settler farms.

The adoption of cash crops was uneven and dependent on the suitability of the soil and the access to markets (Tosh 1980). In largely agricultural economies, the potential productivity of the soil is taken as an indicator of possible per capita incomes (Ashraf and Galor 2011). Michalopoulos and Papaioannou (2013, pp. 124-25), for example, use a measure of the suitability of land for agriculture to control for pre-colonial incomes. Bandyopadhyay and Green (2016, p. 480) use the shallowness of the soils and clay content to account for geographical determinants of development outcomes. In our study, we use the water-holding capacity of the soil as an indicator of soil quality. ${ }^{11}$ In Africa, with its low-technology rain-fed agriculture, availability of water is the main determinant of crop production (Leenaars, Claessens, Heuvelink, Hengl, Ruiperez Gonzalez, van Bussel, Guilpart, Yang, and Cassman. 2018, p. 1).

To capture market access, our analysis includes the number of railway stations per 1,000 inhabitants in each Native Authority area and the distance to the nearest major city. ${ }^{12}$ Railway networks in Africa were not extensive, but where they existed transport costs were considerably lower (Chaves, Engerman, and Robinson 2014; Herranz-Loncan and Fourie 2018). They also shaped the economic geography of African countries to a large degree, promoting urbanization and the development of domestic markets (Jedwab and Moradi 2016; Jedwab, Kerby, and Moradi 2017; Buckwalter 2019). Cities were important centers of demand for agricultural produce, both for local consumption and for export, as exports were often traded through capitals before being shipped overseas. Researchers often use distance to the coast as an indicator of access to export markets.

\footnotetext{
${ }^{11}$ Soil quality data from the Africa Soil Information Service, http://africasoils.net/services/ data/soil-databases/.

${ }^{12}$ Measured as the shortest distance from the geometric mean of each Native Authority area to the nearest big city, obtained from colonial censuses. Railway stations per Native Authority area were calculated using lists or maps of individual railway stations as follows: Gold Coast Railway (1948); East African Railways and Harbours (1951); Nyasaland map, Royal Geographic Society mr Malawi S/G.5; Nigeria (1948).
} 
TABLE 4

SUBNATIONAL ECONOMIC INEQUALITIES AND PER CAPITA REVENUE

\begin{tabular}{lcccc}
\hline \hline & $\begin{array}{c}\text { Revenue } \\
\text { per Capita }\end{array}$ & $\begin{array}{c}\text { Revenue } \\
\text { per Capita }\end{array}$ & $\begin{array}{c}\text { Revenue } \\
\text { per Capita }\end{array}$ & $\begin{array}{c}\text { Revenue } \\
\text { per Capita }\end{array}$ \\
\hline Cash crop dummy & $11.04^{* * *}$ & $10.07^{* * *}$ & $11.36^{* * *}$ & $11.31^{* * *}$ \\
& $(3.26)$ & $(2.80)$ & $(3.23)$ & $(3.22)$ \\
Distance to large city & & $-0.0384^{* * *}$ & $-0.0302^{* *}$ & $-0.0303^{* *}$ \\
& & $(-3.09)$ & $(-2.45)$ & $(-2.46)$ \\
Railway stations & & & $11.33^{* *}$ & $11.29^{* *}$ \\
$\quad$ per 1,000 population & & & $(2.54)$ & $(2.52)$ \\
Soil water capacity & & & & -0.124 \\
& & & & $(-0.23)$ \\
Constant & $20.89 * * *$ & $29.91 * * *$ & $24.84^{* * *}$ & $17.55^{*}$ \\
& $(7.26)$ & $(6.99)$ & $(5.39)$ & $(1.69)$ \\
\hline Country dummies & Yes & Yes & Yes & Yes \\
$N$ & 189 & 189 & 189 & 189 \\
$R^{2}$ & 0.319 & 0.334 & 0.358 & 0.359 \\
\hline
\end{tabular}

Notes: $t$-statistics adjusted for heteroscedasticity in parentheses. Significance levels: ${ }^{*} p<0.10$, $* * p<0.05, * * * p<0.01$.

Sources: Hailey surveys, U.K. National Archives CO 1018. Soil water capacity from Leenaars et al. (2018).

However, as exports were shipped from particular centers rather than from just anywhere on the coast, distance to major cities provides a more contextually relevant measure.

This paper uses a simple ordinary least squares (OLS) model to illustrate the relationships between economic opportunity and revenue per capita. As noted above, the intention is to offer a descriptive analysis rather than identify channels of causation, and what is presented here are correlations in which causality could run in either direction. Table 4 shows the results of this analysis.

The variables on cash crop production and market access are all strongly significant with the expected signs. Production of a cash crop has a coefficient of between 10 and 11, as compared with a mean revenue per capita of 39 pence for the regression sample. The coefficient for railway stations per 1,000 people is similar in magnitude. Distance from large cities is consistently associated with lower revenue collection.

The only variable that does not have the expected relationship with revenue per capita is soil quality. Following previous literature, the water-holding capacity of the soil should be positively related to revenue per capita. In our sample, it is actually negatively correlated with revenue per capita in all colonies except for Kenya, where the relationship is positive. However, in the regression sample, the correlation is consistently 
insignificant. To check this result, we substituted various measures of soil quality, such as organic carbon stock, clay content, capacity to contain nutrients, $\mathrm{Ph}$, bulk density, and a combination of all of these using factor analysis. None of the variables showed a strong and positive relationship with revenue per capita.

This lack of relationship is perhaps not as surprising as it seems. Soil mapping is not a precise science. In his contribution to the History of Cartography, Millea (2015, p. 1448) notes that maps attempting to capture the "general kind of soil that tends to form in a particular climate" often miss "the site-scale variability that occurs as a result of local geology, slope, internal drainage, vegetation cover and prior land use." African soil maps, in particular, are often based on very limited and low-quality data (Showers 2005, pp. 215-16). Finally, the relationship between soil quality and tax revenue is potentially ambiguous. Fenske (2014) argues that African state building is linked to ecological diversity, which provided opportunities for specialization and trade, rather than to overall fertility.

Native Authority revenue per capita is, thus, unsurprisingly related to differences in the opportunities available to African farmers for market production. As noted above, there is a potential for reverse causation in these relationships. Two of the significant variables considered in this section, railway stations per 1,000 and proximity to cities, are plausibly exogenous, since the location of both railways and urban centers was in most cases determined before the introduction of Native Authority treasuries. Other studies of the impact of colonial transport infrastructure have argued that, because the locations were determined by a mix of strategic, political, and economic factors, causal relationships can be established (Jedwab and Moradi 2016; Bertazzini 2018). However, decisions by African farmers to introduce cash crops may have been partly related to the Native Authorities' capacity to enforce land rights or provide other agricultural services.

Differences in agricultural incomes are unlikely to be the whole story, as suggested by histories of fiscal development elsewhere. In his history of European fiscal development, Dincecco (2015, pp. 907-08) notes that tax receipts in England and France increased much faster than per capita incomes. In Africa today, Teera and Hudson (2004) also observe numerous examples of countries with similar levels of per capita income but very different levels of tax revenue as a share of GDP, and they find that per capita income is insignificant as a determinant of tax revenue as a share of GDP after controlling for institutional variables. Stotsky and Wolde-Mariam (1997) also argue that differences in tax effort can be explained by institutional differences. 


\section{INTERGOVERNMENTAL RELATIONS \\ AND NATIVE AUTHORITY REVENUE}

The history of indirect rule above showed that African chiefs' levels of authority and autonomy varied under colonial rule. This section considers the implications of this variation for the Native Authorities' ability to collect tax revenue. Previous work on colonial governance has speculated about the impact of this variation on later development outcomes. Findings have been mixed. Lange (2004), for example, finds a negative relationship between the degree of indirect rule (measured by the share of legal cases decided in Native Courts) and measures of postindependence political development. However, other work that focuses on local institutions or the services they provide often finds the opposite. For example, in her work on India, Iyer (2010) finds greater availability of public sector goods, such as schools, health centers, and roads, in indirectly ruled areas. The degree of indirect rule is often used, albeit anecdotally, to explain why pre-colonial state centralization - measured by the Murdock (1967) jurisdictional hierarchy variable — is associated with better development outcomes. Gennaioli and Rainer (2007) argue that greater local accountability of chiefs as a result of more centralized precolonial states explains the greater provision of public goods in countries with a larger share of population from ethnic groups that traditionally had more centralized state institutions.

In literature that is not specific to Africa or indirect rule, we find that theories of fiscal decentralization also predict a positive relationship between local autonomy and per capita revenue. This work often draws a distinction between the devolution of power and delegation of administrative functions (Bardhan 2002, p. 186). Poschl and Weingast (2015) argue that local governments, which rely primarily on their own revenue rather than transfers from the central government, tend to be more responsive in the provision of public goods. This logic is similar to that of the colonial decentralization policies discussed earlier.

To measure the autonomy of Native Authorities within the colonial state, this paper proposes a reinterpretation of data commonly used to measure the structure of pre-colonial institutions. These data come from George P. Murdock's Ethnographic Atlas (1967). The Atlas was based on a survey of early anthropological research from the nineteenth and early twentieth centuries on societies from around the world, including a large number in Africa. It codes a wide range of variables on issues such as agriculture, marriage practices, and religion. In recent research, the most widely used variable from the Murdock data is "jurisdictional 
TABLE 5

MURDOCK JURISDICTIONAL HIERARCHY SCORES FOR NIGERIA NATIVE AUTHORITIES

\begin{tabular}{lcc}
\hline \hline & Northern Nigeria & Southern Nigeria \\
\hline Organized NA & 2.25 & 3.6 \\
Unorganized NA & 1.85 & 1.96 \\
\hline
\end{tabular}

Source: "Native Treasuries Estimates," 1936-7, in CO 657/43. Lower scores for northern Nigeria reflect the practice of giving centralized emirates control over less centralized societies in the area. For example, see Paden (1970, p. 172).

hierarchy," or "the number of jurisdictional levels in each society" (Murdock 1967, p. 160). Using this as an indicator of pre-colonial state centralization is controversial, as observation of the societies included in the Murdock Atlas started in 1830 at the earliest, with the 1920s being the most common decade of observation (Henderson and Whatley 2014). We, instead, interpret the Murdock data as reflecting early European perceptions of African states, which then informed colonial policies. On the basis of these perceptions, additional powers were devolved to Native Authorities in African states that were deemed to be more centralized, or hierarchical. In regions with African states that appeared less centralized, Native Authorities more often acted as delegates of the colonial state.

Evidence to support this argument is not just anecdotal. The colonial government in Nigeria, for example, classified Native Authorities as "organized" and "unorganized." The former were allowed to retain a larger share of the direct tax revenue they collected on behalf of the colonial state and given greater authority over some government functions. In particular, they had greater discretionary powers over the allocation of expenditure, including salaries and capital spending. ${ }^{13}$ This classification correlates well with the Murdock scores, suggesting that those groups perceived by early European observers to be more centralized were also more likely to be classified as organized by colonial governments. Table 5 shows the average jurisdictional hierarchy scores from the Murdock Atlas for organized and unorganized Native Authorities in both northern and southern Nigeria.

Table 6 shows the results of an OLS regression in which we add the Murdock jurisdictional hierarchy variable to the model developed in the previous section. We measured the degree of political centralization for each Native Authority by pairing the colonial maps of the Native Authorities with a map of the geographical location of indigenous societies, originally created by Murdock (1959) and digitized by Nunn (2008),

\footnotetext{
13 “Native Treasuries Estimates," 1936-1937, in CO 657/43.
} 
TABLE 6

AUTONOMY AND REVENUE PER CAPITA

\begin{tabular}{|c|c|c|c|c|}
\hline & $\begin{array}{l}\text { Revenue } \\
\text { per Capita }\end{array}$ & $\begin{array}{l}\text { Revenue } \\
\text { per Capita }\end{array}$ & $\begin{array}{l}\text { Revenue } \\
\text { per Capita }\end{array}$ & $\begin{array}{l}\text { Revenue } \\
\text { per Capita }\end{array}$ \\
\hline Cash crop dummy & $\begin{array}{l}8.474 * * \\
(2.48)\end{array}$ & $\begin{array}{c}14.03 * * * \\
(4.15)\end{array}$ & $\begin{array}{l}11.34 * * * \\
(3.21)\end{array}$ & $\begin{array}{c}11.07 * * * \\
(3.31)\end{array}$ \\
\hline Distance to large city & $\begin{array}{c}-0.0383 * * * \\
\quad(-3.09)\end{array}$ & $\begin{array}{c}-0.0344^{* * *} \\
\quad(-2.83)\end{array}$ & $\begin{array}{c}-0.0314 * * \\
(-2.48)\end{array}$ & $\begin{array}{c}-0.0271^{* *} \\
(-2.10)\end{array}$ \\
\hline $\begin{array}{c}\text { Railway stations per } \\
1,000 \text { population }\end{array}$ & $\begin{array}{l}9.77 * * \\
(2.22)\end{array}$ & $\begin{array}{c}10.25 * * \\
(2.35)\end{array}$ & $\begin{array}{c}11.85^{* *} \\
(2.55)\end{array}$ & $\begin{array}{c}10.70^{* *} \\
(2.46)\end{array}$ \\
\hline $\begin{array}{l}\text { NA jurisdictional hierarchy } \\
\text { (Murdock) }\end{array}$ & $\begin{array}{l}6.788 * * * \\
(3.16)\end{array}$ & & & \\
\hline Traditional selection NA & & $\begin{array}{c}12.45 * * * \\
(3.89)\end{array}$ & & \\
\hline NA sets budget & & & $\begin{array}{c}17.38 * * * \\
(3.20)\end{array}$ & \\
\hline Presence appeal court & & & & $\begin{array}{c}8.873 * * \\
(2.39)\end{array}$ \\
\hline Constant & $\begin{array}{c}13.98^{* *} \\
(2.31)\end{array}$ & $\begin{array}{c}24.01 * * * \\
(5.30)\end{array}$ & $\begin{array}{l}15.61 * * * \\
(2.88)\end{array}$ & $\begin{array}{l}21.29 * * * \\
(4.22)\end{array}$ \\
\hline Country dummies & Yes & Yes & Yes & Yes \\
\hline$N$ & 189 & 189 & 189 & 189 \\
\hline$R^{2}$ & 0.382 & 0.382 & 0.359 & 0.380 \\
\hline
\end{tabular}

$t$-statistics adjusted for heteroscedasticity in parentheses. Significance levels: ${ }^{*} p<0.10,{ }^{* *} p<$ $0.05, * * * p<0.01$.

Sources: Hailey surveys, U.K. National Archives CO 1018.

and assigning societies to Native Authorities based on this comparison. We cross-checked these assignments using information from the Hailey surveys on the ethnic composition of the populations of Native Authority jurisdictions. We then calculated a weighted average of the political centralization score in which the weights were determined by the share of the area inhabited by different societies. As expected, this variable has a positive and significant relationship with revenue per capita. The scale of the coefficient is a bit lower than that of the cash crop and railway variables above but still substantial (6.79 as compared to mean revenue per capita of 39 pence), and the coefficients of the other variables remain significant.

It may be that the jurisdictional hierarchy score is proxying for something else. To check for robustness, we substituted for the Murdock score several other measures of the autonomy of the Native Authorities coded from the Hailey surveys, shown in columns $2-4$. Owing to variations in the specificity of the survey responses, these are coded mostly as dummy variables reflecting various aspects of the division of authority between the Native Authority and the colonial government. We added these to 
the model one at a time as they are often correlated with one another. The first indicates whether the chief's appointment was by traditional selection, rather than by appointment by the colonial state. The relationship between revenue per capita and traditional selection is positive and significant, and of a scale similar to the effect of producing cash crops or having an additional railway station.

Another such variable is a dummy for whether the Native Authority sets its own budget estimates, as opposed to this being done entirely or partly by the district officer. This variable has a large and significant positive relationship with revenue per capita, with a coefficient of 17.38 , close to double the size of the coefficients of the economic variables previously discussed. Finally, the model considers whether the Native Courts in that jurisdiction had appellate powers. This also has a positive and significant coefficient, of 8.87 .

This section shows that, even controlling for differences in economic structure and market access, the degree of autonomy possessed by Native Authorities is associated with higher levels of revenue per capita. Those that were perceived as more centralized, able to select their own chiefs and set their own estimates, were able to collect more in tax revenue than those without such powers. These variables are clearly endogenous and the causality could run in both directions. Qualitative evidence on Native Authority autonomy presented above shows that colonial administrations took into account the resources available to Native Authorities before devolving responsibility for providing services, and as a result, those better able to raise resources may have had more autonomy. At the same time, as noted above, wider studies of decentralization support the link between the power of a local government to determine its own expenditures and its ability to collect taxes.

\section{STRUCTURE OF NATIVE AUTHORITIES AND NATIVE AUTHORITY REVENUE}

There is a substantial historical literature on the relationship between political institutions and tax payments, which focuses particularly on the willingness of taxpayers to pay. While our data do not include direct information on tax compliance per se, they can show that internal structural differences still help explain differences in revenue per capita, even controlling for economic inequalities and intergovernmental relations. Much of the literature on political institutions and tax revenue, whether using historical or contemporary evidence, stresses a link between political voice and tax payments. However, debates persist about the influence of 
TABLE 7

NATIVE AUTHORITY STRUCTURE

\begin{tabular}{|c|c|c|c|c|}
\hline & $\begin{array}{l}\text { Revenue } \\
\text { per Capita }\end{array}$ & $\begin{array}{l}\text { Revenue } \\
\text { per Capita }\end{array}$ & $\begin{array}{l}\text { Revenue } \\
\text { per Capita }\end{array}$ & $\begin{array}{l}\text { Revenue } \\
\text { per Capita }\end{array}$ \\
\hline Cash crop dummy & $\begin{array}{l}9.996 * * * \\
(2.93)\end{array}$ & $\begin{array}{l}11.30^{* * *} \\
(3.44)\end{array}$ & $\begin{array}{c}10.21 * * * \\
(2.90)\end{array}$ & $\begin{array}{l}9.010 * * * \\
(2.62)\end{array}$ \\
\hline Distance to large city & $\begin{array}{c}-0.0406 * * * \\
(-3.35)\end{array}$ & $\begin{array}{c}-0.0443 * * * \\
(-3.55)\end{array}$ & $\begin{array}{c}-0.0426 * * * \\
(-3.36)\end{array}$ & $\begin{array}{l}-0.0358 * * * \\
(-2.77)\end{array}$ \\
\hline $\begin{array}{c}\text { Railway stations per } \\
1,000 \text { population }\end{array}$ & $\begin{array}{l}9.11 * * \\
(2.05)\end{array}$ & $\begin{array}{c}10.04 * * \\
(2.36)\end{array}$ & $\begin{array}{l}9.44 * * \\
(2.16)\end{array}$ & $\begin{array}{l}9.75 * * \\
(2.32)\end{array}$ \\
\hline $\begin{array}{l}\text { NA jurisdictional hierarchy } \\
\text { (Murdock) }\end{array}$ & $\begin{array}{l}6.069 * * * \\
(2.71)\end{array}$ & $\begin{array}{l}6.032 * * * \\
(2.87)\end{array}$ & $\begin{array}{l}5.989 * * * \\
(2.78)\end{array}$ & $\begin{array}{c}6.868^{* * *} \\
(3.14)\end{array}$ \\
\hline Chief in council & $\begin{array}{c}13.20 * * * \\
(3.47)\end{array}$ & & & \\
\hline Solo chief & $\begin{array}{c}11.20 * * * \\
(3.15)\end{array}$ & & & \\
\hline Elected NA & & $\begin{array}{c}-11.90 * * * \\
(-3.53)\end{array}$ & & \\
\hline Number of chiefs per NA & & & $\begin{array}{c}-0.428^{* * *} \\
(-2.81)\end{array}$ & \\
\hline Removal by the people & & & & $\begin{array}{l}5.756 \\
(0.96)\end{array}$ \\
\hline Constant & $\begin{array}{l}24.86 * * * \\
(2.89)\end{array}$ & $\begin{array}{l}17.16^{* * *} \\
(2.89)\end{array}$ & $\begin{array}{l}22.23 * * * \\
(3.11)\end{array}$ & $\begin{array}{c}13.09 * * \\
(2.07)\end{array}$ \\
\hline Country dummies & Yes & Yes & Yes & Yes \\
\hline$N$ & 189 & 189 & 189 & 189 \\
\hline$R^{2}$ & 0.410 & 0.403 & 0.391 & 0.386 \\
\hline
\end{tabular}

$t$-statistics adjusted for heteroscedasticity in parentheses. Significance levels: ${ }^{*} p<0.10,{ }^{* *} p<$ $0.05, * * * p<0.01$.

Sources: Hailey surveys, U.K. National Archives CO 1018.

particular political structures. It has frequently been argued, for example, that representative regimes have greater fiscal capacity (Feld and Frey 2002; Dincecco 2015). However, not all studies find a direct link between type of government and fiscal capacity, and political voice may be expressed in a variety of regime types (Johnson 2006; Karaman and Pamuk 2010; Timmons 2010; Rosenthal and Wong 2011; Johnson and Koyama 2017).

The Hailey surveys allow for several indicators of institutional structure to be added to the model constructed above. Table 7 presents these results. One indicator is whether the Native Authority is comprised of a chief in council rather than a solo chief or council only. As noted earlier, councils were introduced to Native Authorities particularly to allow for the voices of groups such as migrants or mission-educated Africans who were not necessarily part of traditional hierarchies. This variable 
is positive and significant, with a coefficient of 13.2, or just over a third of the standard deviation in revenue per capita. A dummy variable for whether a Native Authority was comprised of a solo chief is also positive and significant, relative to the reference category of Native Authorities comprised only of a council. Modern studies of traditional leadership in African countries have found that the presence of chiefs plays an important coordinating role in development projects (Baldwin 2016). The apparent importance of having both a chief and council in terms of raising revenue suggests something similar may have been true of Native Authorities. The apparent importance leadership may offer some explanation for why Native Authorities with chiefs (with or without councils) were able to collect more revenue per capita than those led by a council only. This may also help explain the negative sign on the coefficient for elected Native Authorities, which lacked a traditionally selected chief.

We also find a significant, though small $(-0.43)$, negative coefficient for the variable indicating the number of chiefs per Native Treasury. Smaller Native Authorities were often required to federate for financial purposes, as mentioned earlier. This relationship suggests that difficulties in coordinating several chiefs may have limited revenue collection to some extent, or at the very least that federating did not overcome existing structural disadvantages for these areas.

The accountability of chiefs also appears to have been important. A dummy indicating whether chiefs can be removed from their position also has a positive coefficient, though not significant. In her study of indirect rule in India, Iyer (2010) argues similarly that the fact that rulers could be removed "in cases of 'misrule"" appears to play quite an important role. This finding also fits Mamdani's (1996) characterizations of African institutions under indirect rule as "decentralized despotism." The inability of a chief to become a despot seems to have been associated with higher revenues.

Again, it is important to note that the channels of causality may run in both directions. Studies of local government taxation in other contexts suggest that the payment of taxes may incentivize greater vigilance on the part of taxpayers and greater efforts to be involved in decision making. Poschl and Weingast (2015, p. 166) note that, if citizens are made to pay taxes, they are "more inclined to watch over or scrutinize the government's activities and to demand representation in government and influence policy discussions." With cross-sectional data, it is not possible to say, for example, whether the presence of councils drove an increase in tax revenue or whether the response of taxpayers to an increase in tax demands was behind the creation of a council. 
TABLE 8

RESULTS FOR SUBSAMPLE OF DECENTRALIZED NATIVE AUTHORITIES

\begin{tabular}{|c|c|c|c|c|}
\hline & $\begin{array}{l}\text { Revenue } \\
\text { per Capita }\end{array}$ & $\begin{array}{l}\text { Revenue } \\
\text { per Capita }\end{array}$ & $\begin{array}{l}\text { Revenue } \\
\text { per Capita }\end{array}$ & $\begin{array}{l}\text { Revenue } \\
\text { per Capita }\end{array}$ \\
\hline Cash crop dummy & $\begin{array}{c}8.415^{* * *} \\
(2.67)\end{array}$ & $\begin{array}{c}11.04 * * * \\
(3.79)\end{array}$ & $\begin{array}{l}8.994 * * * \\
(2.73)\end{array}$ & $\begin{array}{c}6.929 * * \\
(2.16)\end{array}$ \\
\hline Distance to large city & $\begin{array}{c}-0.0220 \\
(-1.37)\end{array}$ & $\begin{array}{c}-0.0325^{* *} \\
(-2.00)\end{array}$ & $\begin{array}{c}-0.0219 \\
(-1.31)\end{array}$ & $\begin{array}{c}-0.0168 \\
(-1.03)\end{array}$ \\
\hline $\begin{array}{c}\text { Railway stations per } \\
1,000 \text { population }\end{array}$ & $\begin{array}{l}5.890 \\
(0.92)\end{array}$ & $\begin{array}{l}7.832 \\
(1.65)\end{array}$ & $\begin{array}{l}6.290 \\
(0.99)\end{array}$ & $\begin{array}{l}6.696 \\
(1.06)\end{array}$ \\
\hline NA sets budget & $\begin{array}{l}22.88 * * * \\
(2.74)\end{array}$ & $\begin{array}{c}23.84 * * * \\
(3.02)\end{array}$ & $\begin{array}{c}23.88 * * * \\
(2.96)\end{array}$ & $\begin{array}{c}24.35^{* * *} \\
(3.10)\end{array}$ \\
\hline Chief in council & $\begin{array}{l}6.933^{*} \\
(1.91)\end{array}$ & & & \\
\hline Solo chief & $\begin{array}{c}9.488 * * * \\
(2.84)\end{array}$ & & & \\
\hline Elected NA & & $\begin{array}{c}-14.21 * * * \\
(-3.66)\end{array}$ & & \\
\hline Number of chiefs per NA & & & $\begin{array}{c}-0.337 * * \\
(-2.12)\end{array}$ & \\
\hline Removal by the people & & & & $\begin{array}{l}-2.217 \\
(-0.33)\end{array}$ \\
\hline Constant & $\begin{array}{c}15.43 * * * \\
(2.83)\end{array}$ & $\begin{array}{c}24.41 * * * \\
(5.08)\end{array}$ & $\begin{array}{c}26.69 * * * \\
(4.49)\end{array}$ & $\begin{array}{l}21.16^{* * *} \\
(4.09)\end{array}$ \\
\hline Country dummies & Yes & Yes & Yes & Yes \\
\hline$N$ & 124 & 124 & 124 & 124 \\
\hline$R^{2}$ & 0.339 & 0.368 & 0.330 & 0.318 \\
\hline
\end{tabular}

$t$-statistics adjusted for heteroscedasticity in parentheses. Significance levels: ${ }^{*} p<0.10,{ }^{* *} p<$ $0.05, * * * p<0.01$.

Sources: Hailey surveys, U.K. National Archives CO 1018.

One counter-argument might be, particularly given the limited data on per capita incomes, that our results simply reflect the wider implications of higher levels of state centralization, as measured by Murdock. A number of the sources we have cited previously argue that local inequalities in Africa are largely the result of the persistent legacies of historical characteristics, whether through wealth (Bandyopadhyay and Green 2016) or through some function of centralized pre-colonial institutions (Michalopoulos and Papaioannou 2013, 2014). To address this point, Table 8 presents the same analysis for only those Native Authorities without centralized state structures. ${ }^{14}$ Substituting for the Murdock

${ }^{14}$ We include only those Native Authorities with a score of three or less on the Murdock jurisdictional hierarchy measure. 
measure of autonomy, which unsurprisingly is not significant in this subsample, is the dummy for whether the Native Authority sets its own estimates, as discussed in the previous section on intergovernmental relations. This proxy for the autonomy of the Native Authority remains positive, significant, and large throughout the analysis.

The results remain quite stable, with coefficients similar in size to those in the full model presented in previous sections, though some of the variables lose significance in this subsample. ${ }^{15}$ Importantly, the variables that capture both autonomy and political voice and accountability of the Native Authorities all remain similar to the full model, except whether or not the people can de-stool the chief, which becomes smaller and changes signs but remains insignificant.

The indicators of political voice and accountability of Native Authorities point to mechanisms at work in the subsample that are similar to those in the full model presented above. Most importantly, the dummy indicating the presence of a chief-in-council structure remains positively associated with revenue per capita, while the number of chiefs per treasury remains negatively associated. For the Native Authorities in states perceived by early European officials to be less centralized, both the autonomy and the political voice and accountability that developed during the colonial period played a significant role in the development of fiscal capacity. This suggests that the story is not driven merely by the underlying affluence or capacity of African states that were centralized early on.

\section{CONCLUSION}

The literature on colonial institutions and their legacies takes two approaches to explaining the relative importance of Africans and Europeans in shaping them. The first emphasizes European decisionmaking, ignoring the influence of pre-colonial institutions. The second, swinging too far in the other direction, minimizes the impact of the European institutions and argues that pre-colonial institutions remained more influential. In this paper, we argue that both approaches miss a foundational feature of colonial rule: the dynamic interaction between African elites and the colonial state.

Using new data on tax revenues collected by Native Authorities in four British colonies in Africa from c. 1948, the paper shows that differences in fiscal capacity between local governments were linked to a range of economic, social, and political factors: market access, the relationship between Native Authorities and the colonial state, and the structure of

\footnotetext{
${ }^{15}$ For full results for the subsample of decentralized societies, see Online Appendix 3.
} 
the Native Authorities themselves. Even those Native Authorities that colonial officials before 1914 perceived as less organized could influence revenue collection through their chiefs' and councils' decisions. A message we want to convey strongly in this paper is that one-sided data - either on European policy or on African states - will not suffice to explain the structure and legacies of colonial institutions. We now need a more systematic study of how these two interacted as both European officials and African elites responded to the political, economic, and social changes of the twentieth century.

The four colonies considered here, Nigeria, the Gold Coast, Nyasaland, and Kenya, were all British, which may raise questions about how far our argument can be generalized to other parts of Sub-Saharan Africa. Other colonial powers were probably no less dependent on African intermediaries than the British, and their interactions with African elites may also have produced institutions that helped to shape the experience and legacy of colonialism. ${ }^{16}$

The collection of local data represents one of the new frontiers of African economic history. Future data collection efforts are bound to yield more systematic information, giving us a more comprehensive understanding of the institutions that governed African populations under colonial rule. Such study should not be restricted to tax revenue. Writing more generally about the economic history of state institutions, Hoffman (2015, p. 327) notes that courts, government spending, and other services "cry out for study," along with taxation. The extent to which Native Authorities helped shape the "uneven institutional topography" of local African political organization today (Boone 2003, pp. 37-38) remains largely unknown. Economic historians have a long way to go in understanding the role Africans played and how they shaped the development of the continent.

Historian David Killingray (Institute of Commonwealth Studies 2013) once joked that the ideal exam question for a course on African colonialism might be: "During colonial rule, Africa was mainly governed by Africans. Discuss." Our paper takes a first step toward investigating the truth of that statement.

\section{REFERENCES}

Aboagye, Prince Young, and Jutta Bolt. “Economic Inequality in Ghana, 1891-1960.” African Economic History Network Working Paper 38, Lund University, Lund, Sweden, 2018.

\footnotetext{
${ }^{16}$ See, for example, the comparison of two Yoruba kingdoms under British and French rule in Asiwaju (1970).
} 
Acemoglu, Daron, and James Robinson. Why Nations Fail: The Origins of Power, Prosperity and Poverty. London: Profile Books, 2012.

Afigbo, A. E. The Warrant Chiefs: Indirect Rule in Southeastern Nigeria, 1891-1929. London: Longman, 1972.

African Development Bank. African Economic Outlook. Abidjan: African Development Bank, 2015.

Amin, Samir. "Underdevelopment and Dependence in Black Africa." Social and Economic Studies 22, no. 1 (1973): 177-96.

Archibong, Belinda. "Historical Origins of Persistent Inequality in Nigeria." Oxford Development Studies 46, no. 3 (2018): 325-47.

_. "Explaining Divergence in the Long-Term Effects of Precolonial Centralization on Access to Public Infrastructure Services in Nigeria." World Development 121 (2019): 123-40.

Ashraf, Quamrul, and Oded Galor. "Dynamics and Stagnation in the Malthusian Epoch." American Economic Review 101, no. 5 (2011): 2003-41.

Asiwaju, I. A. "The Alaketu of Ketu and the Onimeko of Meko: The Changing Status of Two Yoruba Rulers under French and British Rule." In West African Chiefs: Their Changing Status under Colonial Rule and Independence, edited by M. Crowder and O. Ikime, 134-60. Ile-Ife: University of Ife Press, 1970.

Atanda, J. A. "The Changing Status of the Alafin of Oyo under Colonial Rule and Independence." In West African Chiefs: Their Changing Status under Colonial Rule and Independence, edited by M. Crowder and O. Ikime, 212-30. Ile-Ife: University of Ife Press, 1970.

Baldwin, Kate. The Paradox of Traditional Chiefs in Democratic Africa. New York: Cambridge University Press, 2016.

Bandyopadhyay, Sanghamitra, and Elliott Green. "Pre-Colonial Political Centralization and Contemporary Development in Uganda." Economic Development and Cultural Change 64 (2016): 471-508.

Bardhan, Pranab. "Decentralization of Governance and Development." Journal of Economic Perspectives 16, no. 4 (2002): 185-205.

Bayly, C. A. "Indigenous and Colonial Origins of Comparative Economic Development." World Bank Policy Working Paper 4474, Washington, DC, 2008.

Berry, Sara. "Hegemony on a Shoestring: Indirect Rule and Access to Agricultural Land." Africa 62 (1992): 327-55.

Bertazzini, Mattia C. "The Long-Term Impacts of Italian Colonial Roads in the Horn of Africa, 1935-2000.” LSE Economic History Working Paper 272, London, 2018.

Bertocchi, Graziella, and Fabio Canova. "Did Colonization Matter for Growth? An Empirical Exploration into the Historical Causes of Africa's Underdevelopment." European Economic Review 46 (2002): 1851-71.

Boahen, A. Adu. "New Trends and Processes in Africa in the Nineteenth Century." In General History of Africa Vol. 1: Africa in the Nineteenth Century until the 1880s, edited by J.F. Ade Ajayi. Paris: UNESCO, 1989.

Boone, Catherine. Political Topographies of the African State: Territorial Authority and Institutional Choice. Cambridge, UK: Cambridge University Press, 2003.

Bolt, Jutta, and Leigh Gardner. "Replication: How Africans Shaped British Colonial Institutions: Evidence from Local Taxation" Ann Arbor, MI: Inter-university Consortium for Political and Social Research [distributor], 2020-XX-XX. https:// doi.org/10.3886/E120581V1. 
Broadberry Stephen, and Leigh Gardner. "Economic Development in Africa and Europe: Reciprocal Comparisons." Revista de Historia Economica 34, no. 1 (2016): 11-37. Buckwalter, Laura Maravall. "The Impact of a 'Colonizing River': Colonial Railways and the Indigenous Population in French Algeria at the Turn of the Century." Economic History of Developing Regions 34, no. 1 (2019): 26-47.

Chaves, Isaac, Stanley Engerman, and James Robinson. "Reinventing the Wheel: The Economic Benefits of Wheeled Transportation in Early Colonial British West Africa." In Africa's Development in Historical Perspective, edited by Emmanuel Akyeampong, Robert Bates, Nathan Nunn, and James Robinson, 489-512. Cambridge: Cambridge University Press, 2014.

Cell, J. "Lord Hailey and the Making of the African Survey." African Affairs 88 (1989): 481-505.

Chelliah, R. J. "Trends in Taxation in Developing Countries." IMF Staff Paper 18, Washington, DC, 1971.

Crowder, Michael, and Obaro Ikime, eds. West African Chiefs: Their Changing Status under Colonial Rule and Independence. Ile-Ife: University of Ife Press, 1970.

de Haas, Michiel. "Measuring Rural Welfare in Colonial Africa: Did Uganda's Smallholders Thrive?” Economic History Review 70, no. 2 (2017): 605-31.

de Roo, Bas. "Taxation in the Congo Free State, an Exceptional Case? (1885-1908)." Economic History of Developing Regions 32, no. 2 (2017): 97-126.

Dincecco, Mark. Political Transformations and Public Finances: Europe, 1650-1913. Cambridge: Cambridge University Press, 2011.

_. "The Rise of Effective States in Europe." Journal of Economic History 75, no. 3 (2015): 901-18.

Dudley, B. J. Parties and Politics in Northern Nigeria. London: Frank Cass \& Co., 1968.

Dziobek, Claudia, Carlos Gutierrez Mangas, and Phebby Kufa. "Measuring Fiscal Decentralization: Exploring the IMF's Databases." IMF Working Paper WP/11/126, Washington, DC, 2011.

Easterly, William, and Ross Levine. "The European Origins of Economic Development." Journal of Economic Growth 21 (2016): 225-57.

Falola, Toyin. Colonialism and Violence in Nigeria. Bloomington: Indiana University Press, 2009.

Feld, Lars P., and Bruno S. Frey. "Trust Breeds Trust: How Taxpayers Are Treated." Economics of Governance 3, no. 2 (2002): 87-99.

Fenske, James. "Ecology, Trade and States in Pre-Colonial Africa." Journal of the European Economic Association 12, no. 3 (2014): 612-40.

Fortes, Meyer, and Edward E. Evans-Pritchard. "Introduction." In African Political Systems, edited by Meyer Fortes and Edward E Evans-Pritchard, 1-24. Oxford: Oxford University Press, 1966.

Frankema, Ewout. "Colonial Taxation and Government Spending in British Africa, 1880-1940: Maximizing Revenue or Minimizing Effort?" Explorations in Economic History 48, no. 1 (2011): 136-49.

Frankema, Ewout, and Morten Jerven. "Writing History Backwards or Sideways: Towards a Consensus on African Population, 1850-2010." Economic History Review 67, no. 4 (2014): 907-931.

Frankema, Ewout, and Marlous van Waijenburg. "Structural Impediments to African Growth? New Evidence from Real Wages in British Africa, 1880-1965.” Journal of Economic History 72, no. 4 (2012): 895-926. 
. "Metropolitan Blueprints of Colonial Taxation? Lessons from Fiscal Capacity Building in British and French Africa, c. 1880-1940." Journal of African History 55 (2014): 371-400.

Frankema, Ewout, Jeffrey Williamson, and Pieter Woltjer. “An Economic Rationale for the West African Scramble? The Commercial Transition and the Commodity Price Boom of 1835-1885." Journal of Economic History 78, no. 1 (2018): 231-367.

Gardner, Leigh. Taxing Colonial Africa: The Political Economy of British Imperialism. Oxford: Oxford University Press, 2012.

Gennaioli, Nicola, and Ilia Rainer. "The Modern Impact of Precolonial Centralization in Africa." Journal of Economic Growth 12 (2007): 185-234.

Gerring, John, John Gerring, Daniel Ziblatt, Johan Van Gorp, and Julián Arévalo. “An Institutional Theory of Direct and Indirect Rule." World Politics 63, no. 3 (2011): $377-433$.

Hailey, William. An African Survey: A Study of the Problems Arising in Africa South of the Sahara. London: Oxford University Press, 1938.

- Native Administration in British Tropical Africa. London: HMSO, 1942.

- Native Administration in the British African Territories. London: HMSO, 1951.

Hawthorne, Walter. "States and Statelessness." In The Oxford Handbook of Modern African History, edited by John Parker and Richard Reid, 77-93. Oxford: Oxford University Press, 2013.

Henderson, Morgan, and Warren Whatley. "Pacification and Gender in Colonial Africa: Evidence from the Ethnographic Atlas.” MPRA Working Paper 61203, Munich, Germany, 2014.

Herranz-Loncan, Alfonso, and Johan Fourie. “'For the Public Benefit?' Railways in the British Cape Colony.” European Review of Economic History 22 (2018): 73-100.

Hicks, Ursula K. Development from Below: Local Government and Finance in Developing Countries of the Commonwealth. Oxford: Clarendon Press, 1961.

Hinden, Rita, ed. Local Government and the Colonies. London: George Allen and Unwin, 1950.

Hoffman, Philip T. "What Do States Do? Politics and Economic History." Journal of Economic History 75, no. 2 (2015): 303-32.

Huillery, Elise. "The Impact of European Settlement within French West Africa: Did Pre-Colonial Prosperous Areas Fall Behind?” Journal of African Economies 20, no. 2 (2011): 263-311.

Iliffe, John. Africans: The History of a Continent. Cambridge, UK: Cambridge University Press, 2007.

Institute of Commonwealth Studies. "Indirect Rule - Right or Wrong? A Transcript of the Proceedings of the Seminar Held on 29 March 2012." Occasional Paper of the OSPA Research Project 6, Lexington, KY, 2013.

Iyer, Lakshmi. "Direct versus Indirect Colonial Rule in India: Long-Term Consequences." Review of Economics and Statistics 92, no. 4 (2010): 693-713.

Jedwab, Remi, Edward Kerby, and Alexander Moradi. "History, Path Dependence and Development: Evidence from Colonial Railways, Settlers and Cities in Kenya." Economic Journal 127 (2017): 1467-94.

Jedwab, Remi, and Alexander Moradi. "The Permanent Effects of Transportation Revolutions in Poor Countries: Evidence from Africa." Review of Economics and Statistics 98, no. 2 (2016): 268284. 


\section{How Africans Shaped British Colonial Institutions}

Johnson, Noel D. "Banking on the King: The Evolution of the Royal Revenue Farms in Old Regime France." Journal of Economic History 66, no. 4 (2006): 963-91.

Johnson, Noel D., and Mark Koyama. "States and Economic Growth: Capacity and Constraints." Explorations in Economic History 64 (2017): 1-20.

Karaman, K. Kivanc, and Sevket Pamuk. "Ottoman State Finances in European Perspective 1500-1914." Journal of Economic History 70, no. 3 (2010): 593629.

- "Different Paths to the Modern State in Europe: The Interaction between Warfare, Economic Structure, and Political Regime." American Political Science Review 107, no. 3 (2013): 603-26.

Kirk-Greene, A. H. M. "The Thin White Line: The Size of the British Colonial Service in Africa." African Affairs 79 (1980): 25-44.

La Porta, Rafael, Florencio Lopez-de-Silanes, and Andrei Shleifer. "The Economic Consequences of Legal Origins.” Journal of Economic Literature 46, no. 2 (2008): 285-332.

Ladouceur, Paul André. Chiefs and Politicians: The Politics of Regionalism in Northern Ghana. London: Longman, 1979.

Lange, Matthew. "British Colonial Legacies and Political Development." World Development 32, no. 6 (2004): 905-22.

Lange, Matthew, James Mahoney, and Matthias vom Hau. "Colonialism and Development: A Comparative Analysis of Spanish and British Colonies." American Journal of Sociology 111 (2006): 1412-62.

Leenaars, J. G. B, L. Claessens, G. B. M. Heuvelink, T. Hengl, M. Ruiperez Gonzalez, L. G. J. van Bussel, N. Guilpart, H. Yang, and K. G. Cassman. "Mapping Rootable Depth and Root Zone Plant-Available Water Holding Capacity of the Soil of Sub-Saharan Africa." Geoderma 324 (2018): 18-36.

Lessmann, Christian, and Andre Seidel. "Regional Inequality, Convergence and Its Determinants: A View from Outer Space.” European Economic Review 92 (2017): $110-32$.

Levi, Margaret. Of Rule and Revenue. Berkeley: University of California Press, 1988.

Lieberman, Evan S. "Taxation Data as Indicators of State-Society Relations: Possibilities and Pitfalls in Cross-National Research." Studies in Comparative International Development 36, no. 4 (2002): 89-115.

Lonsdale, J. M. "Some Origins of Nationalism in East Africa." Journal of African History IX, no. I (1968): 119-46.

Mamdani, Mahmoud. Citizen and Subject: Contemporary Africa and the Legacy of Late Colonialism. Princeton: Princeton University Press, 1996.

Michalopoulos, Stelios, and Elias Papaioannou. "Pre-Colonial Ethnic Institutions and Contemporary African Development." Econometrica 81 (2013): 113-52.

- "National Institutions and Subnational Development in Africa." Quarterly Journal of Economics 129, no. 1 (2014): 151-213.

Miers, Suzanne. "Slavery and the Slave Trade as International Issues 1890-1939." Slavery and Abolition 19, no. 2 (1998): 16-37.

Millea, Nick. "Soils Map." In The History of Cartography, Volume Six: Cartography in the Twentieth Century, edited by Mark Monmonier, 1443-52. Chicago: University of Chicago Press, 2015.

Mkandawire, Thandika. "On Tax Efforts and Colonial Heritage in Africa." Journal of Development Studies 46, no. 10 (2010): 1647-69. 
Murdock, George P. Africa: Its Peoples and Their Culture History. New York: McGraw Hill, 1959.

Murdock, George P. "Ethnographic Atlas: A Summary.” Ethnology 6 (1967): 109236.

Musgrave, Richard. Fiscal Systems. London: Yale University Press, 1969.

Mveyange, Anthony. "Night Lights and Regional Income Inequality in Africa." UNU-WIDER Working Paper 085, Helsinki, Finland, 2015.

Naseemullah, Adnan, and Paul Staniland. "Indirect Rule and Varieties of Governance." Governance 29, no. 1 (2016): 13-30.

Nunn, Nathan. "The Long-Term Effects of Africa's Slave Trades." Quarterly Journal of Economics 123, no. 1 (2008): 139-76.

Ogbomo, Onaiwu W. "Revolutionary Changes in the Nineteenth Century." In Precolonial Nigeria: Essays in Honor of Toyin Falola, edited by Akinwumi Ogindiran, 473-89. Trenton, NJ: Africa World Press, 2005.

Okauru, I. O. A Comprehensive Tax History of Nigeria. Ibadan: Safari Books, 2012.

Osadolor, Osarhieme B., and Leo E. Otoide. "State Formation in Precolonial Nigeria: A Historiographic Assessment." In Precolonial Nigeria: Essays in Honor of Toyin Falola, edited by Akinwumi Ogindiran. Trenton, NJ: Africa World Press, 2005.

Osafo-Kwaako, Philip, and James Robinson. "Political Centralization in Pre-Colonial Africa." Journal of Comparative Economics 41 (2013): 6-21.

Paden, J. N. "Aspects of Emirship in Kano.” In West African Chiefs: Their Changing Status under Colonial Rule and Independence, edited by M. Crowder and O. Ikime, 162-86. Ile-Ife: University of Ife Press, 1970.

Poschl, Caroline, and Barry R. Weingast. "A Fiscal Interest Approach to Subnational Government Incentives." In Is Decentralization Good for Development? Perspectives from Academics and Policy Makers, edited by Jean-Paul Faguet and Caroline Poschl. Oxford: Oxford University Press, 2015.

Reid, Richard. A History of Modern Africa: 1800 to the Present. Chichester: WileyBlackwell, 2009.

Roberts, Richard. "Coerced Labor in Twentieth-Century Africa." In The Cambridge World History of Slavery, Volume 4: AD 1804-AD 2016, edited by David Eltis, Stanley L. Engerman, Seymour Drescher, and David Richardson. Cambridge: Cambridge University Press, 2017.

Rosenthal, Jean-Laurent, and R. Bin Wong. Before and Beyond Divergence: The Politics of Economic Change in China and Europe. Cambridge, MA: Harvard University Press, 2011.

Schumpeter, Joseph A. “The Crisis of the Tax State.” In International Economic Papers: Translations Prepared for the International Economic Association, edited by A. T. Peacock. London: Macmillan, 1954.

Showers, Kate. “On Mapping African Soils.” Environmental History 10 (2005): 314-20.

Spear, Thomas. "Neo-Traditionalism and the Limits of Invention in British Colonial Africa." Journal of African History 44, no. 1 (2003): 3-27.

Stotsky, Janet Gale, and Asegedech Wolde-Mariam. "Tax Effort in Sub-Saharan Africa." IMF Working Paper WP/97/107, Washington, DC, 1997.

Teera, Joweria M., and John Hudson. "Tax Performance: A Comparative Study." Journal of International Development 15 (2004): 785-802.

Tilly, Charles. Coercion, Capital and European States, AD 990-1990. Cambridge, MA: Blackwell, 1990. 
Timmons, Jeffrey F. "Taxation and Representation in Recent History." Journal of Politics 72, no. 1 (2010): 191-208.

Tosh, John. "The Cash-Crop Revolution in Tropical Africa: An Agricultural Reappraisal." African Affairs 79, no. 314 (1980): 79-94.

Van Waijenburg, Marlous. "Financing the African Colonial State: The Revenue Imperative and Forced Labor." Journal of Economic History 78, no. 1 (2018): 40-80.

\section{GOVERNMENT REPORTS}

East African Railways and Harbours. Reports of the Commissioner for Transport. Nairobi: Government Printer, 1951.

Gold Coast. Census of Population. Accra: Government Printer, 1948.

- Report on Local Government Finance. Accra: Government Printer, 1952.

Gold Coast Railway. Official Tariff Book No. 3, $1^{\text {st }}$ December 1948. Accra: Government Printer, 1948.

Kenya. Report on Native Affairs 1939-45. Nairobi: Government Printer, 1948.

. Report on Native Affairs 1947-8. Nairobi: Government Printer, 1949.

Nigeria. Annual Report on the Government Railway for the Financial Year 1947-48. Lagos: Government Printer, 1948.

- Population Census 1952-3. Lagos: Government Printer, 1955.

Nyasaland. Report of the Native Welfare Committee for the Year Ending $31^{\text {st }}$ December 1936. Blantyre: Government Printer, 1937.

_. Provincial Annual Reports. Blantyre: Government Printer, various.

\section{ARCHIVES}

Bodleian Library

Royal Geographical Society

U.K. National Archives 